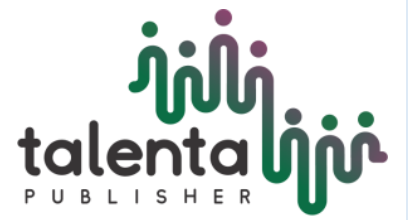

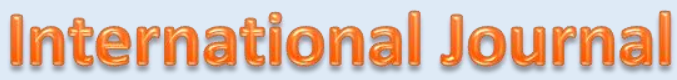 of Ecophysiology
}

\section{Effect of Nano herbal Haramounting (Rhodomyrtus tomentosa) in Histology of Heart Mus musculus}

\author{
Putri Cahaya Situmorang ${ }^{1 *}$, Syafruddin Ilyas ${ }^{1}$ \\ ${ }^{1}$ Department of Biology, Faculty of Mathematics and Natural Sciences, Universitas Sumatera Utara, \\ Medan, Jl. Dr.Mansyur Medan, Indonesia, 20155
}

\begin{abstract}
The objective of this study was to determine the effect of histology of heart Mus musculus after giving Nano Herbal Rhodomyrtus tomentosa (Haramonting). R.tomentosa (Haramonting) is made on a nanoscale using High Energy Milling (HEM). This research use the Completely Randomized Design (CRD). Treatment consists of 6 groups, namely: Control: CMC 0.5\%; T1:100mg/20gBW; T2: 141,42mg/20gBW; T3:200mg/20gBW; T4: $282,82 \mathrm{mg} / 20 \mathrm{gBW} ; \mathrm{T} 5: 400 \mathrm{mg} / 20 \mathrm{gBW}$. The results of histology hearts that there were significant difference $(\mathrm{P}<0,05)$ between control group and treatment groups but there was not significantly different in weight of hearts $(\mathrm{P}>0,05)$.
\end{abstract}

Keywords: Nano Herbal, Rhodomyrtus tomentosa, Histology, Heart

Received 1 June 2019 | Revised 1 July 2019 | Accepted 31 August 2019

\section{Introduction}

Nanotechnology and study of nanoscale has grown rapidly over the past few years in large numbers with various product results. This provides opportunities for material development ie for medical applications, where conventional techniques can reach their limits (Ratnam et al, 2006) The marketed nano herbal products are Aegis. Lifepak Nano, Nano phyto proflex, Nano garcinia raspberry, Nano green coffee, Nano D3. Curcuma longa, Gymnema sylvestre, salvia miltiorrhiza, proteins and many more. Hence nano herbal drugs has become the broad view of new nanotech era for better and safer health care (Rajeshwar et al, 2018). Nanotechnology commonly refers to structures that are up to several $100 \mathrm{~nm}$ in size which can be increased up to $1000 \mathrm{~nm}$. Nanoscale materials have a particle size of a billionth of a meter (Haskel, 2019). The use of herbal medicines has been practiced for thousands of years ago and has a smaller effect compared to synthetic drugs, In addition, the presence of dietary supplements and nutraceuticals derived from plants also play a role in improving herbs in the

\footnotetext{
*Corresponding author at: Universitas Sumatera Utara, Jl. Dr.Mansyur Medan, Indonesia, 20155

E-mail address: syafruddin6@usu.ac.id 
market (Thapa et al, 2013). Herbal remedies have hundreds of constituent constituents that all work together to fight disease (Yadav et al, 2011). Various nanoscale materials such as nanomaterials, nanoparticles, nanocomposers, nanoenergy, nanomedicine and nanoherbal. Therefore the size of the drug given is smaller than the size of the cells of the human body, the drug ingredients are easy to the cell and a better bioavailability reaction occurs, like bacterial cells, The drug ingredients has a smaller particle size than bacterial cells will cause the drug ingredients to easily penetrate bacterial cells, thus inhibiting bacterial growth more quicklyt (Vijaykumar et al, 2010)

Rhodomyrtus tomentosa in Indonesia, especially in North Sumatra, is called haramonting Rhodomyrtus tomentosa (Aiton) Hassk. (Family Myrtaceae) is an ornamental, evergreen shrub grows up to four meters tall. This plant species is native to southern and southeastern Asia (Winotai et al, 2005). The discoveries reported in the study highlight the potential of R.tomentosa as a new source of health-promoting compounds such as dietary fibers, essential fatty acids, and phenolic compounds. A total of 19 phenolic compounds were tentatively characterized, including stilbenes and ellagitannins as major components, followed by anthocyanins, flavonols, and gallic acid. Piceatannol, a promising health-promoting stilbene component (Lai et al, 2013) Studies on $R$. tomentosa mainly focused on the bioactive compounds from leaves and aerial parts because of their antibacterial, DNA damage prevention, and antioxidant activities (Limsuwan et al, 2009). The heart is one of the organs that play a role in the circulatory system. The heart is a vital organ in the body, even though the heart does not target to organ in the toxicity test, this organ can damaged by chemicals compound. So, this study was conducted to determine the safety effect of haramonting on the nanoscale in heart muscle cells.

\section{Materials and Methods}

This research used 30 male mice with an average weight of 20-25g age 12-18 weeks in Biological Laboratory, Faculty Mathematics and Natural Science, Universitas Sumatera Utara. Haramonting is made into a nanoscale using High Energy Milling (HEM). R.tomentosa leaves are washed, then dried in accordance with the requirements of water content using high energy milling (HEM), then Simplicia as the destructive medium is inserted into the jar container, Inserting balls with larger diameter sizethen continued by inserting small balls and the last sample. The total volume of the balls and the samples entered does not exceed $2 / 3$ of the volume of the jar. The usual Ball to Powder Ratio (BPR) is 20:1, 10:1, 8:1. Example BPR 20:1 means 1 gram of sample then milled with 20 grams of ball weight. Jar that has been filled with the ball, samples are closed tightly then mounted on the jar inside the HEM tool, then HEM is turned on for 2 hours. (Situmorang and Ilyas, 2018). 
The treatment consisted of 6 groups consisting of 5 male mice ie Control (CMC 0.5\%) and Nano-R.tomentosa (Haramonting) at T1:100mg/20gBW; T2:141,42mg/20gBW; T3:200mg/20gBW; T4: 282,82mg/20gBW; T5:400mg/20gBW in 14 days, then dissected by the method of disclasio cervicalis to take the heart and made with paraffin method. The data processed with SPSS 22 program with Kruskal Wallis test.

\section{Result and Discussion}
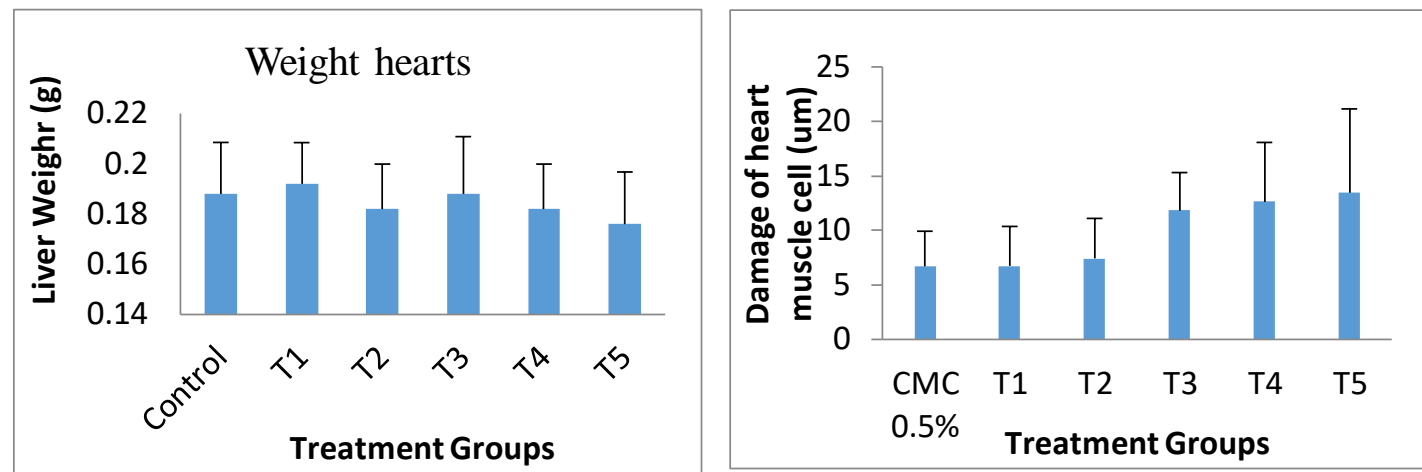

Figure 1. Heart weigh and Increased of heart muscle cell damage $(\bar{X} \pm \mathrm{SD})$.

Weight of heart was not significantly different $(\mathrm{P}>0,05)$. So, Nano-Haramonting cannot affect heart weight. Administration of Nano-R.tomentosa with multilevel doses can cause damage to the heart with Manja Roenigk's histophatolgy model (1: Normal, 2: Parenchymatous Degeneration, 3: Hydrophic Degeneration 4: Necrosis) then the data processed with SPSS 22 program with Kruskal Wallis test. There were significant differences in heart cell damage in each treatment $(\mathrm{P}<0.05)$ except Control group with T1, T3 with T4 and T5 $(\mathrm{P}>0.05)$. The highest increase in $\mathrm{T} 5$ and the lowest damage at CMC 0.5\% (Control) although damage in the control group is almost similar to T1 (Fig.1). Damage to heart muscle tissue due to chemical compounds (drugs) is indicated by the amount of picnotic cell nucleus in the heart, which will cause changes in the function and structure of the heart. In addition to Haramonting, necrosis in the hearts can also be caused by several things such as lack of blood supply, toxin, no nerve innervation, temperature, radioactive light and mechanical trauma (Berata et al, 2011).

Table 1. Average Cell Heart Normal muscle and each degree of damage (Parenchymatous degeneration, Hydrophic degeneration and Necrosis) ( $\bar{X} \pm \mathrm{SD})$.

\begin{tabular}{ccccc}
\hline $\begin{array}{c}\text { Treatment } \\
\text { Gropus }\end{array}$ & Normal & $\begin{array}{c}\text { Parenchymatous } \\
\text { degeneration }\end{array}$ & $\begin{array}{c}\text { Hydrophic } \\
\text { degeneration }\end{array}$ & Necrosis \\
\hline CMC 0.5\% & $13.12 \pm 0.97$ & $5.28 \pm 2.23$ & $6.36 \pm 2.78$ & $8.48 \pm 3.71$ \\
T1 & $12.16 \pm 1.14$ & $9.6 \pm 3.16$ & $4.56 \pm 2.88$ & $6.08 \pm 2.85$ \\
T2 & $11.52 \pm 1.29$ & $9.68 \pm 3.94$ & $5.76 \pm 2.43$ & $6.88 \pm 3.37$ \\
T3 & $7.24 \pm 1.53$ & $11.68 \pm 3.19$ & $11.76 \pm 3.56$ & $12.00 \pm 3.83$ \\
T4 & $5.56 \pm 1.08$ & $16.88 \pm 2.83$ & $8.88 \pm 3.82$ & $12.16 \pm 5.59$ \\
T5 & $3.72 \pm 1.43$ & $20.88 \pm 5.48$ & $8.04 \pm 2.95$ & $12.64 \pm 3.94$ \\
\hline
\end{tabular}



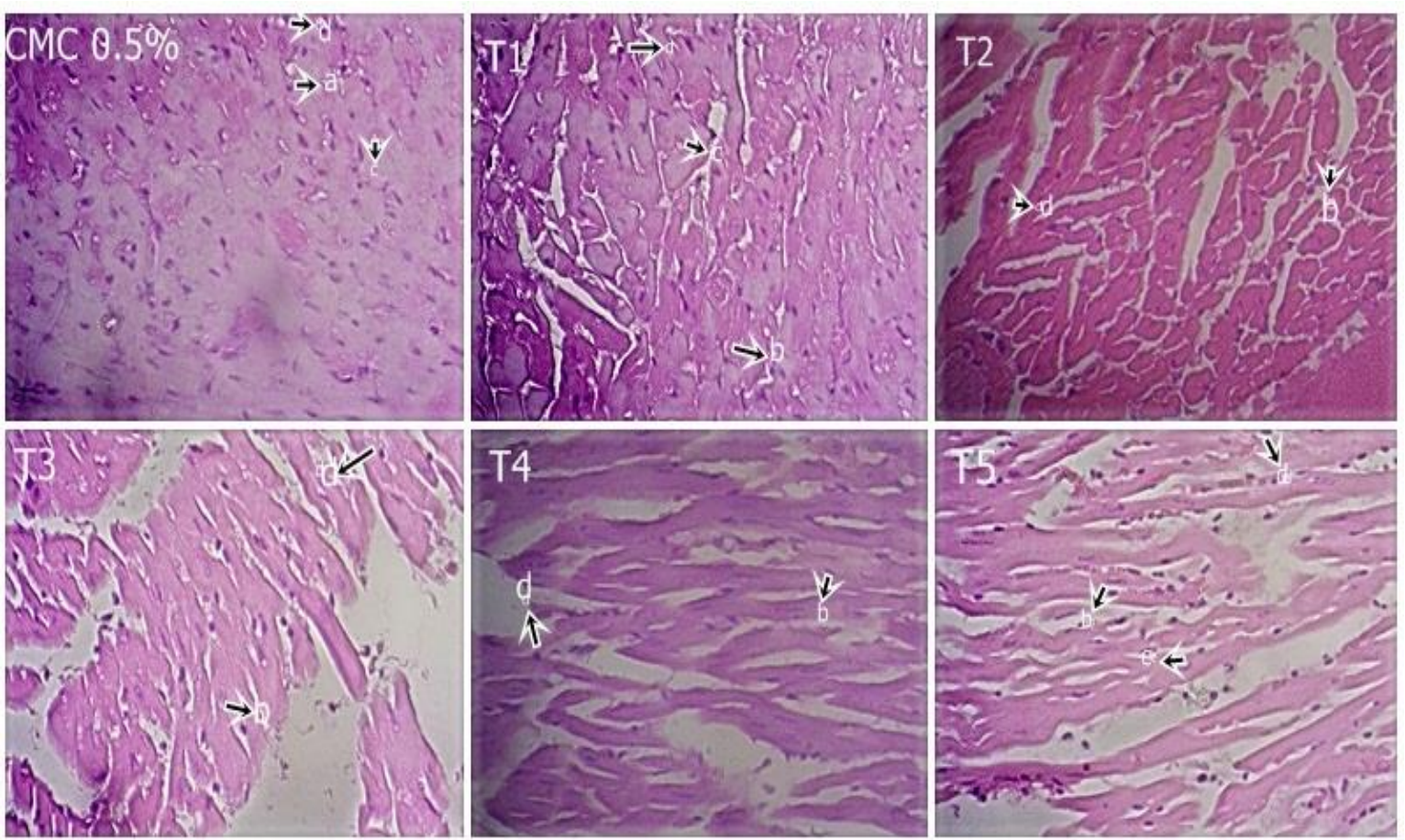

Figure 2. Histology of heart after giving Nano-R.tomentosa (Haramonting), a. Normal. b

Parenchymatous degeneration, b. Hydrophic degeneration, d.Necrosis (400x).

Parenchymatous degeneration occurs more in heart muscle cells and increases from control and every treatment different from hydrophic degeneration and necrosis (table 1). Heart histology is different for each treatment, where the level of necrosis of heart muscle cells is clearly seen in T3, T4 and T5 (figure 2). Based on the degree of damage there was an increase in damage to heart muscle cells in each treatment and began to appear to increase from T2 to T5 (figure 1). Hydrophic degeneration is most common in $\mathrm{T} 3$ and lowest in $\mathrm{T} 1$ while Necrosis increases from control to the highest dose level (table 1). Nano-R.tomentosa with excessive doses causes an increase in necrosis and a decrease in the number of normal hearts cells (table 1). Hydropic degeneration in heart muscle cells is caused by the presence of compounds flavonoids and tannins. Hydrophic and parenchymous degeneration occurs in every treatment of heart cells due to flavonoid and tannin compounds. Tannins have hydroxyl (-OH) which can result in uncoupling of the respiratory chain in mitochondria thus causing ATP to decrease and oxidation failure so that the appearance of granular-granular from the cytoplasm and parenkimatosa degeneration occurs. Stimulation of toxic substances can cause injury to cells by damaging cell membranes, mitochondria and interfere with cell endogenous substrates (Cotran et al, 1999). This is because tannin toxicity can damage cell membranes by shrinking cell walls or cell membrane so interfere with cell wall permeability. Disruption of cell permeability, cells cannot carry out life activities so that cells diet (Juliantina et al, 2009). Haramonting has secondary metabolites such as phenols, flavonoids, saponins, tannins, steroids 
and triterpenoids. Phenol, flavonoids, tannins, steroids and triterpenoids are known to have antioxidant effects. . Saponins can cause hemolysis by influencing lipid bilayers in the protein membranes of red blood cells thus causing pore formation in the red blood cell membrane (Baumann et al, 2005; Gauthier et al, 2009). It is therefore known that the administration of Nano-R.tomentosa at a dose level can cause cell necrosis in muscle hearts.

\section{Conclussion}

There are significant differences in heart cell damage in each treatment $(\mathrm{P}<0.05)$ So, Nano herbal of Haramonting with excessive doses causes increased necrosis in muscle hearts.

\section{Aknowledgement}

We are grateful to Directorate of research and community service, Directorate general of research and development, Ministry of research, Technology, and Higher Education in accordance with research and community service funding agreement for budgeting year 2018 (Fund of the research postgraduate team I) to funding our research.

\section{References}

[1] Baumann E, Stoya G, Volkner A, Richter W, Lemke C, et al. Hemolysis of human erytrocytes with saponin affects the membrane structure. Acta histochemia. 2005.

[2] Berata IK, Winaya IBO, Adi AAAM, Adnyana IBW. Patologi Veteriner Umum. Denpasar: Swasta Nulus.2011

[3] Cotran MD, Kumar V, dan Collins T. Robbins pathologic of disease, 6th ed., WB. Saunders Company, Philadelpia 1999; 6-8, 4-15, $102-110$.

[4] Gauthier C, Legault J, Girard-Lalancette K et al. Haemolytic activity, cytotoxicity and membrane cell permeabilization of semi-synthetic and natural lupane- and oleananetype saponins. Bioorg Med Chem. 2009; 17:2002-8

[5] Haskel R. Nanotechnology in Drug Discovery and Developmeny. Bristol: Myers Squibb 2009;1-8.

[6] Juliantina FR, Citra DA, Nirwani B. Manfaat Sirih Merah (Piper crocatum) sebagai Agen Antibakterial terhadap Bakteri Gram Positif dan Gram Negatif, JKKI; 2009.

[7] Lai TN, Herent MF, Quetin-Leclercq J, Nguyen TB, Rogez H, Larondelle Y, et al. Piceatannol, a potent bioactive stilbene, as major phenolic component in Rhodomyrtus tomentosa. Food Chem 2013;138(2-3):1421-30.

[8] Limsuwan, S, Trip EN, Kouwen TR, Piersma S, Hiranrat A, Mahabusarakam W, et al. Rhodomyrtone: A new candidate as natural antibacterial drug from Rhodomyrtus tomentosa. Phytomedicine, 2009;16(6): 645-651.

[9] Ratnam DV, Ankola DD, Bhardwaj V, Sahana DK, Kumar MN. Role of antioxidants in prophylaxis and therapy: a pharmaceutical prospective, $\mathrm{J}$ control release. Intl journal of mol sci 2006; 113:189-207. 
[10] Rajeshwar V, Shubham B, Jyoti G. Broad View Of Nano Herbal Medicine. Int. J Rec. Adv. Sci. Tech., 2018; 5(2):1-5.

[11] Situmorang PC and Ilyas S. 2018. Description of Testes Histology of Mus musculus after giving nano hebal Rhodomyrtus tomentosa (Haramonting). Asian J Pharm Clin Res 11 issue 11.

[12] Thapa RK, Gulam MK, Kalpana PB, Parbati T. Herbal Medicine Incorporated Nanoparticles: Advancements in Herbal Treatment. Asian J of Biomedl and Pharm Sci 2013; (14) : 7-14.

[13] Vijaykumar, N, Venkateswarlu V and Raviraj P. Development of Oral tablet Dosage from Incorporating Drug Nanoparticles. Res J Pharm Bil chem sci. 2010;1(4): 952-955.

[14] Winotai A, Tony W, and Jhon AG. Herbivores in Thailand on Rhodomyrtus tomentosa (Myrtaceae), an invasive weed in Florida. Flor Ento 2005; 88 (1):104- 105.

[15] Yadav D, et al. Novel Approach: Herbal Remedies And Natural Products In Pharmaceutical Science As Nano Drug Delivery Systems. Int J of Pharm and Tech 2011; 3(3) : 3092-3116 